\title{
Article \\ Structural Model of Power Grid Stabilization in the Green Hydrogen Supply Chain System-Conceptual Assumptions
}

\author{
Marzena Frankowska (D), Marta Mańkowska (D), Marcin Rabe* Andrzej Rzeczycki (D) and Elżbieta Szaruga
}

Institute of Management, University of Szczecin, 71-004 Szczecin, Poland; marzena.frankowska@usz.edu.pl (M.F.) marta.mankowska@usz.edu.pl (M.M.); andrzej.rzeczycki@usz.edu.pl (A.R.); elzbieta.szaruga@usz.edu.pl (E.S.)

* Correspondence: marcin.rabe@usz.edu.pl

check for

updates

Citation: Frankowska, M.;

Mańkowska, M.; Rabe, M.; Rzeczycki, A.; Szaruga, E. Structural Model of Power Grid Stabilization in the Green Hydrogen Supply Chain System-Conceptual Assumptions. Energies 2022, 15, 664. https:// doi.org/10.3390/en15020664

Academic Editor:

Dimitrios Katsaprakakis

Received: 22 November 2021

Accepted: 29 December 2021

Published: 17 January 2022

Publisher's Note: MDPI stays neutral with regard to jurisdictional claims in published maps and institutional affiliations.

Copyright: (C) 2022 by the authors. Licensee MDPI, Basel, Switzerland. This article is an open access article distributed under the terms and conditions of the Creative Commons Attribution (CC BY) license (https:// creativecommons.org/licenses/by/ $4.0 /)$.

\begin{abstract}
The paper presents the conceptual assumptions of research concerning the design of a theoretical multi-criteria model of a system architecture to stabilize the operation of power distribution networks based on a hydrogen energy buffer, taking into account the utility application of hydrogen The basis of the research process was a systematic literature review using the technique of in-depth analysis of full-text articles and expert consultations. The structural model concept was described in two dimensions in which the identified variables were embedded. The first dimension includes the supply chain phases: procurement and production with warehousing and distribution. The second dimension takes into account a comprehensive and interdisciplinary approach and includes the following factors: technical, economic-logistical, locational, and formal-legal.
\end{abstract}

Keywords: hydrogen supply chains; green hydrogen; electricity networks; stabilization model; renewable energy sources

\section{Introduction}

Nowadays, more and more policymakers across the world pay attention to green energy, decarbonization, and applying zero or low-emission solutions in their economies, mainly due to customer pressure [1,2]. With the development of renewable energy sources (RES), the problem of seasonality in energy supply from these sources has arisen. Seasonality concerns both daily and weekly schedules or the system of seasons. One of the concepts for solving this problem is storing electric energy in hydrogen (building a hydrogen buffer). The task of the hydrogen buffer is to stabilize the operation of electric power networks through the conversion of excess electrical energy to so-called "green" hydrogen (electrolyzer), hydrogen storage (warehouse), and conversion of hydrogen to electricity-fuel cell (production and storage phase). The energy stored in hydrogen will serve to meet future demand in situations of periodic shortage. Moreover, hydrogen fuel (distribution phase) can also be used for utility purposes through distribution system operators (e.g., refueling of the vehicle fleet). A by-product of the electrolysis process is oxygen, which may in the future constitute a source of income for the distribution system operators (additional economic benefits).

System stabilization is understood in this context as the balancing of electricity supply and demand, taking into account the resulting transmission losses [3-5]. The development of a system solution that stabilizes the operation of power distribution grids will enable effective electricity management by increasing network flexibility in terms of possibilities for connecting new producers of energy from renewable sources (RES), increasing network security and reliability, as well as improving the quality parameters of supplied electricity [6,7].

In the literature on the subject, there is a paucity of studies integrating the research area of hydrogen supply chains with the functioning of power grids. Thus, the aim of the conducted research is to develop conceptual assumptions for the designed theoretical, multi-criteria architecture model of a system stabilizing the operation of power distribution 
networks on the basis of a hydrogen energy buffer while taking into account the utility application of hydrogen. The conceptual assumptions for the development of the model include the definition of the main layout of the system architecture and the identification of the variables that make up its structure (structural model). The model should include four utility functions [8]:

1. conversion of electricity to hydrogen,

2. fuel cells that convert hydrogen into electricity,

3. hydrogen storage,

4. utility application of hydrogen.

The functions of conversion of electricity to hydrogen, fuel cells that convert hydrogen into electricity, and hydrogen storage enable the stabilization of energy networks through electrolysis. The function of utility application of hydrogen is a supplement to the energy grid stabilization system and enables the additional outlet of energy produced by RES in the form of hydrogen fuel. This gives the distributors of energy networks opportunities to generate additional income.

The article is divided into three parts. The first part presents the purpose and explains the adopted research procedure. The second part presents the results of the conducted literature research showing the current state of knowledge in the development of hydrogen supply chains along with the identified factors of stabilization of energy networks (technical, economic-logistic, localization, and formal-legal). The third part of the article is devoted to the conceptualization of variables in the structural model of the system stabilizing the operation of electric power distribution networks based on a hydrogen energy buffer.

\section{Materials and Methods}

The basis of the research process was a systematic literature review (SLR). In the process of systematic literature review, the technique of in-depth analysis of the full contents of the articles was used. The primary source of data was the Web of Science (WoS) database. The time scope of the analysis covered the period of January-March 2021.

The aim of the SLR was to identify, integrate, and evaluate the state of research in hydrogen supply chain design based on clearly defined criteria. The SLR allowed for the initial identification of variables and then their verification and selection, which enabled the development of a structural model concept. According to the research methodology [9], the literature review included three steps:

1. The identification, classification, and preliminary content analysis included 311 articles selected from the Web of Science (WoS) database according to conceptual categories related to the research objective (keywords): hydrogen, supply chain, storage, renewable sources, model, location, power grid, electrolysis.

2. The selection of key research material included the selection of 42 articles in the areas of hydrogen production and storage from RES by means of electrolysis, fuel cell application, utility application of hydrogen in transportation, and modeling of hydrogen supply chains.

3. An in-depth content analysis of the selected 42 articles was aimed at:

- the identification of technical, economic-logistic, location and formal-legal factors for the purpose of building a structural model,

- the identification of research methods used in the modeling of processes of hydrogen supply, production, storage, and distribution from RES.

The first stage of the SLR began with the formulation of the main and additional research questions. The following main research question was posed:

- What do we know about the potential for stabilizing power networks based on renewable energy sources by using hydrogen technologies?

In order to minimize errors associated with the omission of articles important to the purpose of the study, additional research questions were set: 
- What do we know about renewable energy systems using green hydrogen for energy storage?

- What do we know about the methods and models used to stabilize power grids based on hydrogen storage systems?

- How do hydrogen supply chains that include a storage cell work?

- What factors are considered when identifying hydrogen storage sites?

The formulated research questions were then used to determine the following keywords used to search the WoS database: hydrogen, supply chain, storage, renewable sources, model, location, power grid, and electrolysis. The determined phrases were cross-used in a four-step search. As a result of the search, 311 literature items were identified. Among the preselected 311 sources, there were:

- 197 scientific articles,

- 1 book chapter,

- 76 conference proceedings papers,

- 37 review articles.

In stage two of the SLR, 42 key literature items were selected from a preselected group of 311 articles. The selection of key literature items was based on the analysis of the full texts of the 311 articles. Forty-two items were selected for the second stage of the systematic literature review, including:

- 31 scientific articles,

- 2 conference proceedings papers,

- 9 review articles.

The aim of the in-depth review of 42 items of literature was to identify categories of factors for the structural model in the supply chain phase's system. Thus, the review was directed to identify in the analyzed texts the following variables (factors) relevant to the design and operation of the hydrogen supply chains: technical, economic-logistical, locational, and formal-legal.

To validate the achieved research results in the form of a structural model concept, expert consultations were carried out with representatives of enterprises and scientists representing technical and economic sciences. The consultations allowed for the verification of the factors influencing the stabilization of power networks with the use of the hydrogen buffer obtained in the systematic literature review. Moreover, the strength of the correlation between the various factors was indicated.

A simplified diagram of the conducted research process is presented in Figure 1.

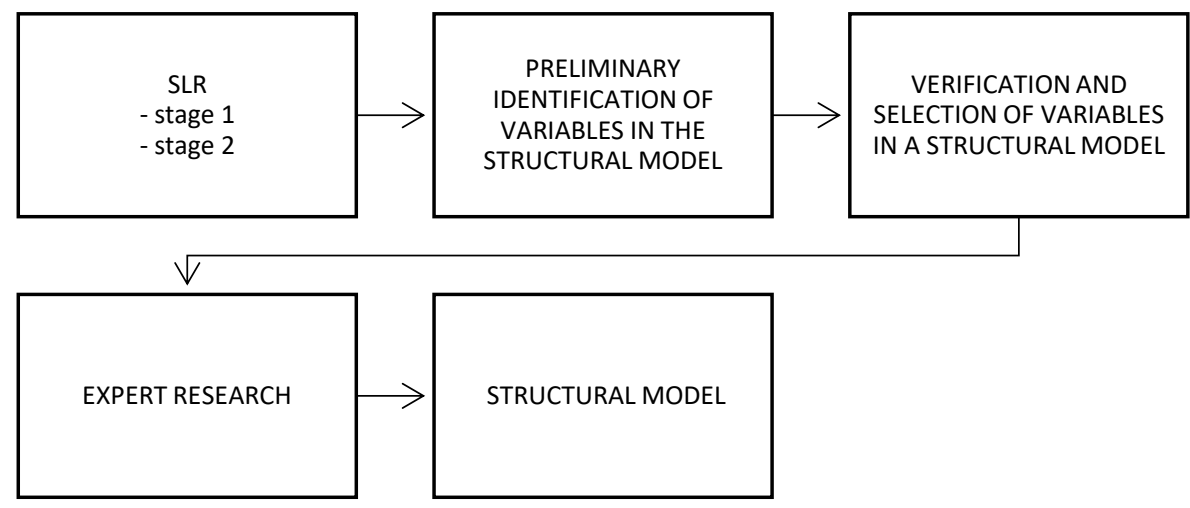

Figure 1. Scheme of the research process.

The choice of the adopted research concept results from the possibility of its application in both technical and social sciences. It also allows for the multi-layered verification of the obtained results. Taking into account the above, the knowledge obtained from the SLR, supplemented with consultations with scientists representing mainly technical sciences (electrical engineering, power engineering, automation, chemical engineering), and verified 
with representatives of business practices (perspective of the distribution system operator) enabled the development of the concept of a multi-criteria theoretical model of architecture stabilizing the operation of power distribution networks based on a hydrogen energy buffer, while taking into account the utility application of hydrogen (structural model).

\section{Results}

\subsection{Theoretical Background}

The first in-depth studies on hydrogen supply chains (mainly from the 2008 to 2012 period) focused primarily on the possible evolution of the hydrogen market, strongly linked to transport. Three main components were distinguished in the hydrogen supply chain structure: hydrogen production subsystem, hydrogen storage subsystem, hydrogen transportation subsystem, and hydrogen refueling station subsystem [10]. In this view, hydrogen supply chain (HSC) research has focused on hydrogen production and storage infrastructure and hydrogen transportation means and processes [11].

These studies did not consider the feedstock phase, which is nowadays recognized as an important component of the HSC. In the first HSC structures, which included the feedstock, four nodes were pointed to [12]: raw material suppliers (local or international), production plants, storage points, and fuel stations. These nodes can be connected by different modes of transport. The supplier sends the raw material to the production plant. At the plant, the raw material is transformed into the final product (liquid or gaseous hydrogen), which is then transported to storage points or directly to refueling stations. From the warehouse, in response to demand, the product is sent to the refueling station. It is also possible to transport the product between storage points. In this approach, however, the specific independence of the individual phases identified in the structure of the hydrogen supply chains is still apparent.

Recent studies present a change in the approach. Hydrogen production through electrolysis is increasingly being considered as an optimal solution. In addition to a more precise determination of the operating costs of the HSC, due to technological progress, a change in the role attributed to hydrogen is particularly highlighted. Hydrogen is treated as an energy carrier and a means of stabilizing the operation of power grids, as well as a raw material for use in various industrial sectors [13]. Since hydrogen technologies are still at a very early stage of development, research has largely focused on strategic HSC planning and the deployment of hydrogen infrastructure. In this context, the importance of the HSC feedstock phase is increasingly pointed out in hydrogen supply chains. It is emphasized [13] that the HSC starts in the feedstock phase and ends with the sale of hydrogen at refueling stations. At the same time, in-depth research on each phase of the HSC is intensively developed due to the existence of many options for their operations. For example, water (with electricity), biomass, and coal can be used as raw material for the production process-electrolysis, biomass gasification, (BG) and coal gasification (CG) processes, respectively [13].

In the feedstock phase, hydrogen as an energy carrier can be produced from different raw materials. Natural gas, coal, biomass, and water (along with electricity from the local power network) are the feedstocks considered in most studies. At the same time, renewable energy sources (RES), including biomass, solar, and wind energy [14] have been increasingly studied in recent years in the context of climate and energy policy challenges related to decarbonization. Nuclear sources are also being considered to achieve mass production of low carbon hydrogen [15].

However, the RES structure is often overlooked in research and excluded from the HSC design model. The cost of purchasing raw materials is included as part of the unit cost of production. On the other hand, the structure, origin (or availability), storage, and transportation of raw materials have been greatly simplified or even completely ignored. At the same time, it is pointed out [13] that, in fact, the initial availability of raw materials plays an important function in the HSC due to the hydrogen supply dependence on regionally unique resource characteristics. The structure of RES sources is also crucial. 
Studies [16], including RES from solar sources, indicate that the art of sustainable operations of grid-integrated wind turbines is rooted in the predesign stage, where adequate reliability studies are required to determine the appropriate location for minimizing transmission losses. At the same time, the necessary integration of solar systems into power grids is associated with technical challenges at the transmission and distribution stages. Few studies also emphasize the importance of the availability of water as the main raw material in the electrolysis process and oxygen, which is the key raw material in coal or biomass gasification $[9,10,17,18]$.

In the HSC production phase, steam methane reforming (SMR), biomass and coal gasification (BG and CG, respectively) and electrolysis are the three main production technologies analyzed in the studies $[19,20]$. It is indicated that currently most of the hydrogen is produced by SMR, which is currently considered the cheapest production method [21]. Nevertheless, significant advantages of electrolysis are indicated in the future. Although the processes are more expensive in this technology, it allows a wider use of hydrogen with a low carbon footprint in the energy system [22-24].

The hydrogen storage phase is considered as a way to cope with production plant outages and demand fluctuations. In addition, as more and more electricity from RES is being introduced into the energy mix, the use of hydrogen storage as an approach to energy storage and a solution to the power grid balancing problem has received increasing attention in recent years. However, it is pointed out that HSC models, which are based on electrolysis-generated hydrogen, require additional seasonal hydrogen storage capacity to bridge the gap between fluctuations in hydrogen generated from surplus renewable electricity and demand from refueling stations [25,26]. Currently, a number of studies are being undertaken in the area of HSC modeling, dealing strictly with the hydrogen storage phase. They are mostly focused on the technical and economic aspects of this solution.

In the transport phase, essentially two options are analyzed. Hydrogen can be transported as liquefied or compressed gas. Liquefied hydrogen can be transported in tankers by rail, road, or sea, while gaseous hydrogen can be transported by high-pressure pipelines or overland transport (in special rail cars or pipe trailers). Tank cars, pipe trailers, and pipelines are the three most commonly selected options for hydrogen transportation. The main factors influencing the choice of hydrogen transportation modes are the hydrogen demand profile (i.e., when and where the demand for hydrogen will arise and the volume of demand) and the distance from the production site to the delivery points [27].

In the distribution phase, two basic types of hydrogen refueling stations are indicated: stations where hydrogen is produced elsewhere and delivered to the station for local storage and distribution to fuel cell electric vehicles (FCEVs) and stations where hydrogen is produced and stored on-site, ready to be transferred to an on-board hydrogen storage facility [28]. Stations that rely on supply can be supplied with liquid or gaseous hydrogen using appropriate distribution techniques. For on-site stations, the most popular production technologies are on-site electrolysis and on-site SMR. On-site electrolysis using grid power is the most commonly used technology in North America, while off-station produced hydrogen supply techniques are the most popular in Europe.

Further research on the planning and operations of HSCs points to the need to fill existing gaps, in particular for in-depth studies on the feedstock phase and on storage seasonality issues. So far, the focus has been mainly on techno-economic issues, without covering in detail the social, regulatory, and policy aspects and the issue of uncertainty about the input data, such as weather conditions, energy prices, and demand that may affect the system operations. It is indicated [29] that future research directions should capture social aspects (e.g., power system security) that may cause consumer rejection of the concept and take into account context-specific conditions (e.g., availability of RES sources, weather) and the uncertainty factor to improve the decision-making process for planning HSC and hydrogen-based power systems.

Moreover, the directions of further research on HSC modeling are determined by the increase in the share of RES power in electric power networks. HSC research should 
therefore give more consideration to aspects of hydrogen production from RES to accelerate the transition to a low-carbon hydrogen economy. Electrolysis, on the other hand, should be considered in the context of storing surplus energy produced from RES and balancing the operation of electric power grids. The link between the energy supply chain and the hydrogen supply chain is presented in Figure 2.

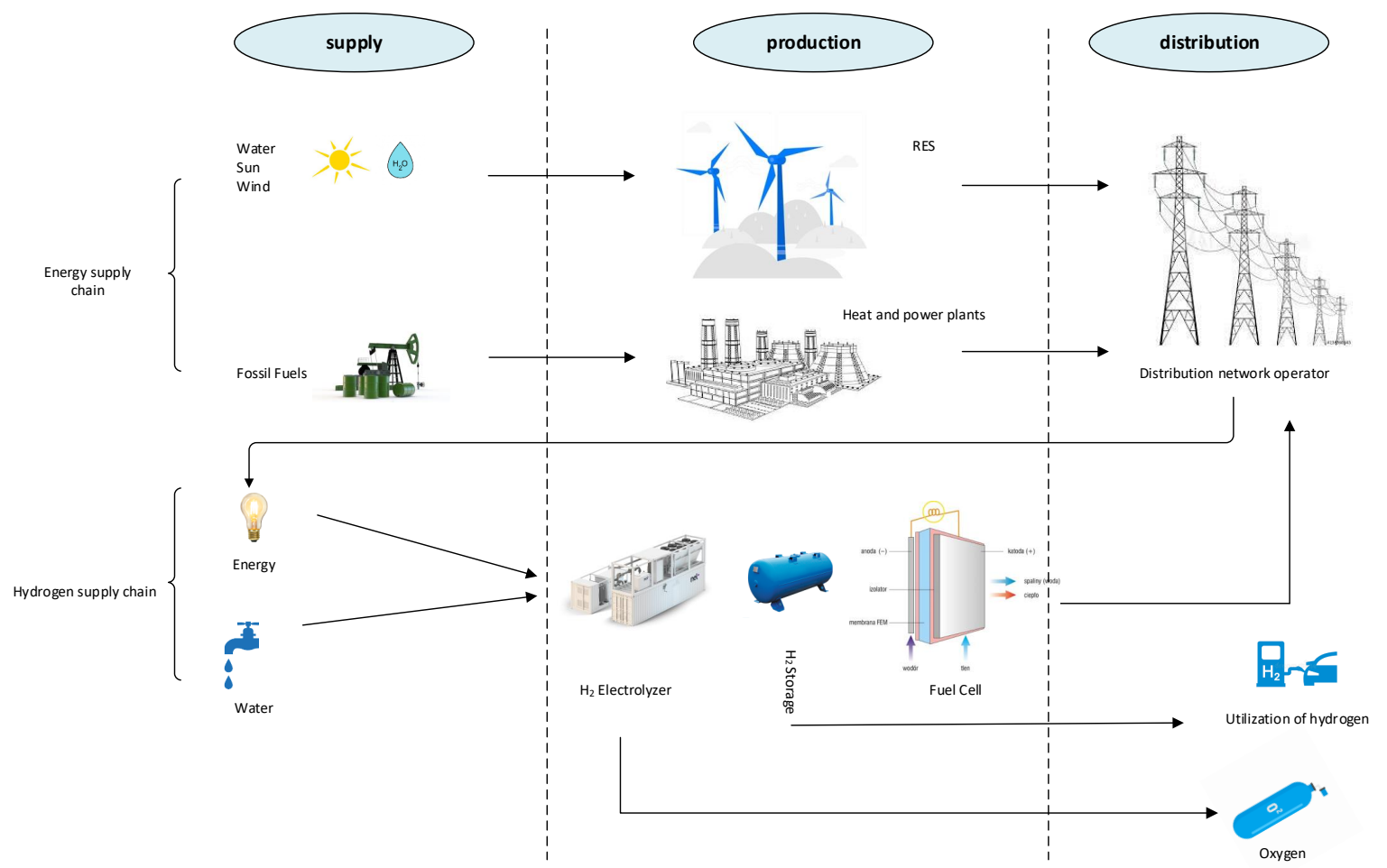

Figure 2. Energy supply chain with hydrogen supply chain. Source: own elaboration.

The link between the development of renewable energy and the use of hydrogen to store surplus electricity is particularly important. The need to store the surplus generated power and balance the power grid is driving the faster development of electrolysis technology. In the electricity grid of the future, dominated by RES energy, hydrogen extracted and transformed by electrolysis will be suitable for a variety of applications: new fuel supply channels, international hydrogen trade, $\mathrm{CO}_{2}$ sequestration, and ancillary services for the electricity grid. More broadly, hydrogen from RES should be considered as a feedstock for some industrial applications.

It can therefore be concluded that future research directions will largely focus on the development of hydrogen fuel cells and hydrogen refueling station networks, including distribution network planning and hydrogen supply cost assessment. This requires a shift in current energy market paradigms. Currently, the price of energy, including electricity, is determined by the price of oil. In the future, assuming the pursuit of an energy mix based $100 \%$ on electricity from renewable sources, the regulatory framework will change. Questions arise as to what parameters will determine the cost of electricity and whether hydrogen produced from surplus electricity from RES will be able to influence the oil market [30].

\subsection{Identification of the Model Variables}

The preliminary extraction of the structural model factors was carried out based on an in-depth analysis of 42 literature items extracted from the 311 articles analyzed (SLR), as indicated in Table 1 . The factors were assigned to each category and phase of the supply chain, as shown in Table 1. 
Table 1. Structural model factors derived from the conducted literature review.

\begin{tabular}{|c|c|c|c|}
\hline $\begin{array}{c}\text { Supply Chain } \\
\text { Phase }\end{array}$ & Group of Factors & Factors & Authors \\
\hline \multirow{4}{*}{ feedstock } & economic and logistical & $\begin{array}{l}\text { - } \quad \text { fixed costs: investment (capital) costs } \\
\text { operating costs: costs of purchasing energy from RES (different for various } \\
\text { RES) } \\
\text { - } \quad \text { operating costs: costs of water purchases } \\
\text { operating costs: other delivery costs } \\
\text { operating costs: e.g., transmission costs } \\
\text { energy network efficiency indicators } \\
\text { inflation } \\
\text { interest rates }\end{array}$ & {$[13,31-37]$} \\
\hline & technical & $\begin{array}{l}\text { - } \quad \text { daily production volume (main power station/source) } \\
\text { - type/percentage share of RES sources (solar, wind, etc.) }\end{array}$ & {$[13,34,35,38-44]$} \\
\hline & formal and legal & - $\quad$ safety (risk) & [45] \\
\hline & locational & $\begin{array}{ll}- & \text { access to water (distance matrix) } \\
- & \text { exclusion factors (land class, Natura 2000, human settlement, etc.) } \\
\text { - } & \text { RES sources } \\
& \text { land development: access to utilities }\end{array}$ & {$[13,46,47]$} \\
\hline \multirow{4}{*}{ production } & economic and logistical & 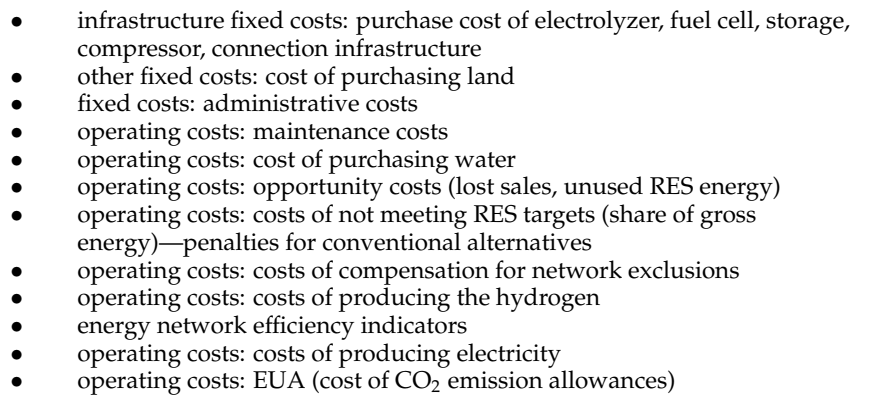 & {$[13,35-37,48-50]$} \\
\hline & technical & $\begin{array}{l}\text { - } \mathrm{H}_{2} \text { production power of the system (maximum value) determined by the } \\
\text { PEM electrolyzer } \\
\text { amount of (daily) } \mathrm{H}_{2} \text { production (real value) determined by the PEM } \\
\text { electrolyzer } \\
\text { - } \quad \text { amount of (daily) energy production-output/power of the fuel cell } \\
\text { - } \quad \text { electricity generation efficiency = fuel cell efficiency } \\
\text { - } \quad \text { the cell-service availability time } \\
\text { energy conversion time to } \mathrm{H}_{2} \\
\text { - } \quad \text { risk of hazard } \\
\text { - } \quad \text { water consumption } \\
\text { energy efficiency of hydrogen production } \\
\text { - } \quad \text { energy efficiency of hydrogen compression } \\
\text { - } \mathrm{H}_{2} \text { consumption by the cell } \\
\text { quality of energy produced by the fuel cell }\end{array}$ & {$[14,31,37,40-42,44,47-52]$} \\
\hline & formal and legal & $\begin{array}{ll}- & \text { social acceptance } \\
\text { - } & \text { safety (risk) } \\
\text { - } & \text { riskatial Development Plan/land development conditions } \\
& \text { risk penalties for fossil fuels }\end{array}$ & {$[45,47]$} \\
\hline & locational & $\begin{array}{l}\text { - } \\
\text { distance of the buffer to the transport network (due to e.g., class of road) } \\
\text { availability of land } \\
\text { relief }\end{array}$ & {$[45,50,53,54]$} \\
\hline storage & economic and logistical & $\begin{array}{l}\text { - } \quad \text { fixed costs: investment costs (fixed costs: warehouse+ compressor) } \\
\text { operating costs: energy storage costs } \\
\text { - } \quad \text { eperating costs: maintenance costs } \\
\text { energy network efficiency indicators }\end{array}$ & $\begin{array}{c}{[31,32,34-} \\
36,38,45,49,51,55-57]\end{array}$ \\
\hline
\end{tabular}


Table 1. Cont.

\begin{tabular}{|c|c|c|c|}
\hline $\begin{array}{c}\text { Supply Chain } \\
\text { Phase }\end{array}$ & Group of Factors & Factors & Authors \\
\hline & technical & $\begin{array}{ll}- & \text { storage size/capacity } \\
- & \text { storage throughput } \\
- & \text { hydrogen density } \\
- & \text { hydrogen pressure } \\
- & \text { storage life (cycles) } \\
- & \text { risk of hazard }\end{array}$ & $\begin{array}{c}{[14,31,33,35,38,} \\
44,46,49,51,52, \\
54,55,58-61]\end{array}$ \\
\hline & formal and legal & - $\quad$ safety (risk) & [45] \\
\hline \multirow{4}{*}{ distribution } & economic and logistical & $\begin{array}{l}\text { - } \quad \text { selling price of fuel cell energy (cost of producing energy for own purposes) } \\
\text { infling price of } \mathrm{H}_{2} \text { (production cost of } \mathrm{H}_{2} \text { for own use) } \\
\text { inflion } \\
\text { - } \\
\text { the cost of transporting } \mathrm{H}_{2} \text { to the station } \\
\text { investment (capital) costs: installation costs } \\
\text { investment (capital) costs: costs of purchasing cars for } \mathrm{H}_{2} \\
\text { - } \quad \text { investment costs (capital costs): costs of purchasing a fleet of tankers } \\
\text { - } \quad \text { average daily demand for electricity on the grid } \\
\text { interest rates } \\
\text { - } \quad \text { distrime of } \mathrm{H}_{2} \text { delivered after compression } \\
\text { - } \quad \text { average daily hydrogen consumption }\end{array}$ & $\begin{array}{c}{[13,14,17,31,35,} \\
36,45,47,49,51- \\
53,57,62]\end{array}$ \\
\hline & technical & 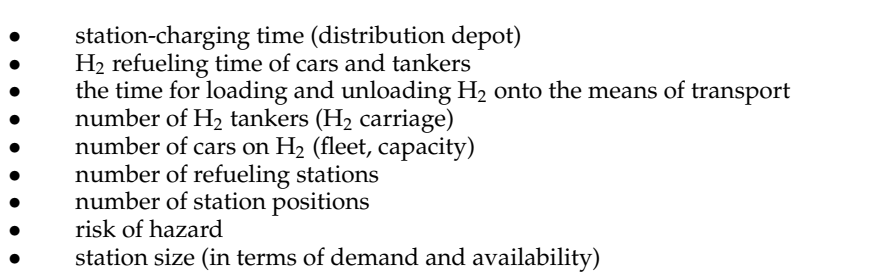 & $\begin{array}{l}{[13,14,36,41,45,} \\
\quad 49,53,57]\end{array}$ \\
\hline & formal and legal & - $\quad$ safety (risk) & {$[45]$} \\
\hline & locational & $\begin{array}{l}\text { - } \quad \text { distance of the charging station from the warehouse } \\
\text { travel time to station }\end{array}$ & {$[17,50]$} \\
\hline
\end{tabular}

Source: own elaboration.

The prepared list of 85 factors was subject to evaluation during brainstorming by experts. As a result of discussions and consultations with experts, key factors from the scope of research were selected by combining and eliminating some of the items. Significance from the point of view of the research goal was taken into account, while simplifying the structure. At the same time, a verification of formal and legal factors resulting from the analysis of national and EU regulations was carried out. As part of the analysis, additional factors were identified, i.e.,:

1. the complexity of the legal regime in the area of hydrogen technologies

2. public support mechanisms for $\mathrm{H}_{2}$ and RES technologies (grants, subsidies, etc.)

3. public support mechanisms for $\mathrm{H}_{2}$ technologies (grants, subsidies, etc.)

4. stability of laws

5. Spatial Development Plan for RES installations

6. Spatial Development Plan for hydrogen buffer

7. Spatial Development Plan for storage

8. permits for connection and access to the grid DSO of the electrolyzer and the fuel cell

9. permits for hydrogen production (legal recognition or restriction of hydrogen energy production)

10. environmental and safety permits

11. hydrogen storage permits

12. hydrogen transport permits (ADRs, packages, cylinders, trailers, drivers, companies) 
13. permits authorizing the construction and operation of the HRS (Spatial Development Plan, safety permits, environmental permits, risks, monitoring)

14. legal status of hydrogen as a fuel

The factors identified in the analysis of literature and legal acts in the next stage of the research were verified by experts. Due to the large number of found factors, the next stages of the research were aimed at narrowing down their number to key and uncorrelated factors.

\section{Discussion and Conclusions}

The objective of the research is to design a theoretical multi-criteria model of a system architecture for stabilizing the operation of electric power distribution networks based on a hydrogen energy buffer, while taking into account the utility applications of hydrogen. In assumption, the model should comprise four utility functions: conversion of electric energy to hydrogen, fuel cell converting hydrogen to electric power, hydrogen storage, and utility application of hydrogen.

The concept of the structural model was described in two dimensions in which the identified variables were embedded. The first dimension includes the supply chain phases: feedstock, production with storage, and distribution. The second dimension considers a comprehensive and interdisciplinary approach and includes the following factors: technical, economic-logistic, localization, and formal-legal. While conceptualizing the variables of the structural model of the system stabilizing the operation of electric distribution networks on the basis of a hydrogen energy buffer, 49 variables were identified. Table 2 shows the assignment of variables in the matrix system of the structural model. In addition, due to the need to determine the role of the identified variables in the mechanism of stabilizing the operation of power distribution networks, they were divided into controllable, noncontrollable, and disturbing variables.

Table 2. Conceptualization of variables in the structural model of the system stabilizing the operation of electric power distribution networks on the basis of a hydrogen energy buffer.

\begin{tabular}{|c|c|c|c|c|}
\hline Supply Chain Phase & Factor Group & Factor & Unit & Type \\
\hline \multirow{18}{*}{ feedstock } & \multirow{5}{*}{ technical } & installed capacity of RES & MW & non-controllable \\
\hline & & structure of RES power & $\%$ & non-controllable \\
\hline & & losses of RES power in $15 \mathrm{kV}$ lines & $\mathrm{kW}$ & disturbing \\
\hline & & transmission capacity of $110 \mathrm{kV}$ lines & MVA & controllable \\
\hline & & transformer capacity in Main Power Station & kWA & controllable \\
\hline & \multirow{6}{*}{ economic-logistical } & volume of RES-generated electrical energy & MWh & non-controllable \\
\hline & & volume of water delivered & $1 / \mathrm{kg}$ & non-controllable \\
\hline & & economic mechanisms of public support & EUR & non-controllable \\
\hline & & costs of modernisation of $110 \mathrm{kV}$ lines and transformers & EUR & controllable \\
\hline & & volume of electricity released from MV grid to HV grid & MWh & disturbing \\
\hline & & energy purchase costs to cover the balance difference & EUR & non-controllable \\
\hline & \multirow{4}{*}{ formal and legal } & complexity of the legal system & Likert scale & non-controllable \\
\hline & & stability of laws and regulations & Likert scale & non-controllable \\
\hline & & non-economic public support mechanisms & Likert scale & non-controllable \\
\hline & & permits and administrative decisions & $<0 ; 1>$ & non-controllable \\
\hline & \multirow{3}{*}{ locational } & availability of land & $<0 ; 1>$ & non-controllable \\
\hline & & proximity to restrictive areas & $<0 ; 1>$ & non-controllable \\
\hline & & attractiveness of location for RES development & Likert scale & non-controllable \\
\hline
\end{tabular}


Table 2. Cont.

\begin{tabular}{|c|c|c|c|c|}
\hline Supply Chain Phase & Factor Group & Factor & Unit & Type \\
\hline \multirow{18}{*}{$\begin{array}{l}\text { production and } \\
\text { storage }\end{array}$} & \multirow{7}{*}{ technical } & PEM electrolyzer power & $\mathrm{kW}$ & controllable \\
\hline & & electrolyzer efficiency & $\mathrm{kWh} / \mathrm{kg}$ & non-controllable \\
\hline & & fuel cell power & $\mathrm{kW}$ & controllable \\
\hline & & fuel cell efficiency & $\mathrm{kWh} / \mathrm{kg}$ & non-controllable \\
\hline & & hydrogen storage capacity & $\mathrm{kg}$ & controllable \\
\hline & & hydrogen storage throughput & $\mathrm{kg} / \mathrm{h}$ & controllable \\
\hline & & hydrogen storage life & number of cycles & non-controllable \\
\hline & \multirow{4}{*}{ ekonomic-logistical } & economic mechanisms of public support (white certificates) & $\begin{array}{l}\% \text { of capital } \\
\text { expenditures }\end{array}$ & non-controllable \\
\hline & & capital expenditures on production infrastructure & EUR & non-controllable \\
\hline & & operating costs of the production phase & EUR/year & non-controllable \\
\hline & & demand of Main Power Station for electricity from the fuel cell & MWh & non-controllable \\
\hline & \multirow{4}{*}{ formal and legal } & complexity of the legal system & Likert scale & non-controllable \\
\hline & & stability of laws and regulations & Likert scale & non-controllable \\
\hline & & non-economic public support mechanisms & Likert scale & non-controllable \\
\hline & & permits and administrative decisions & $<0 ; 1>$ & non-controllable \\
\hline & \multirow{3}{*}{ locational } & acceptance of local community & $<0 ; 1>$ & disturbing \\
\hline & & landforms & altitude & non-controllable \\
\hline & & distance of buffer from transport network & $\mathrm{km}$ & non-controllable \\
\hline \multirow{13}{*}{ distribution } & \multirow{2}{*}{ technical } & distribution capacity & $\mathrm{kg} / \mathrm{h}$ & controllable \\
\hline & & distribution facility lifetime & $<0 ; 1>$ lub $\%$ & disturbing \\
\hline & \multirow{5}{*}{ economic-logistical } & $\begin{array}{l}\text { economic mechanisms of public support (subsidies and tax } \\
\text { relief) }\end{array}$ & EUR & non-controllable \\
\hline & & capital expenditures on distribution infrastructure & EUR & non-controllable \\
\hline & & operating costs of the distribution phase & EUR/year & non-controllable \\
\hline & & revenues from the sale of oxygen & EUR/year & non-controllable \\
\hline & & demand for hydrogen fuel & $\mathrm{kg} / 24 \mathrm{~h}$ & non-controllable \\
\hline & \multirow{4}{*}{ formal and legal } & complexity of the legal system & Likert scale & non-controllable \\
\hline & & stability of laws and regulations & Likert scale & non-controllable \\
\hline & & non-economic public support mechanisms & Likert scale & non-controllable \\
\hline & & permits and administrative decisions & $<0 ; 1>$ & non-controllable \\
\hline & \multirow{2}{*}{ locational } & distance of the distribution facility from the backup storage & $\mathrm{km}$ & non-controllable \\
\hline & & travel time of users to the distribution facility & $\mathrm{h}$ & non-controllable \\
\hline
\end{tabular}

Source: own elaboration.

Summarizing the research findings, it is concluded that there is a paucity of studies in the literature that integrate the research area of hydrogen supply chains with the functioning of electrical power grids. The present research aspires to fill the research and cognitive gap in this area. This is because SLR research in the content analysis of scientific articles has shown that research on modeling hydrogen supply chains is still in its early development stage. The existing literature is dominated by:

1. fragmentary studies in the technical sciences that focus on selected aspects of hydrogen production, storage, or distribution,

2. optimization models based on selected methods of operational research applied in technical sciences.

In particular, SLR has shown that there is a lack of comprehensive research and research methods covering diverse aspects of hydrogen supply chain design and modeling in the context of stabilizing the operation of electric power distribution grids based on a hydrogen energy buffer. In addition, there is a lack of comprehensive and consistent legal regulations conditioning the development of hydrogen supply chains.

The developed conceptual framework for the structural model includes the conceptualization of 49 variables assigned to a two-dimensional system architecture covering 
the three phases of the hydrogen supply chain (feedstock, production with storage, and distribution) in four groups of factors (technical, economic-logistical, locational, and formallegal factors) taking into account the four hydrogen utilities (conversion of electricity to hydrogen, fuel cells converting hydrogen to electricity, hydrogen storage, and hydrogen utility application). The model is related directly to the so-called green hydrogen generated from electricity produced from renewable energy. It takes on particular importance because it may help to limit the use of fossil fuels and apply zero or low-emission solutions, which are the key policy actions in the field of sustainable development of the energy sector and economy. Much effort is made towards the process of energy transformation and decarbonization as well as increasing the share of renewable energy sources (RES) in the supply of primary energy.

The presented model describes a new research area that integrates theoretical achievements in the field of hydrogen supply chains as well as the operation and development of power grids. The indicated common area is also of great application importance. However, in the presented studies the conceptual model identifies the main variables at the overall level of the hydrogen supply chain. Although it allows managers to see the entire spectrum of variables in the hydrogen supply chain, some limitations in its use by managers have been observed.

In the next stage of the work, it is necessary to continue research on the operationalization of variables and the determination of their relationships and interaction. This will ultimately contribute to the development of a systemic solution that will stabilize the operation of the electric power distribution networks and will enable effective electrical energy management, increasing network flexibility with regard to the possibilities of connecting new producers of energy from renewable sources (RES), raising network security and reliability, and improving the quality parameters of the supplied electrical energy.

Author Contributions: Conceptualization, M.F., M.M., M.R., A.R. and E.S.; methodology, M.F., M.M., A.R. and E.S.; software, M.R., A.R. and E.S.; validation, M.F., M.M., M.R., A.R. and E.S.; formal analysis, M.F., M.M., M.R., A.R. and E.S.; investigation, M.F., M.M. and A.R.; resources and data curation, M.F., M.M., M.R., A.R. and E.S.; writing-original draft preparation, M.F., M.M., M.R. and A.R.; writing-review and editing, M.F., M.M., M.R., A.R. and E.S.; visualization, M.R., A.R. and E.S.; supervision, M.F., M.M., M.R., A.R. and E.S.; project administration, M.F., M.M., M.R., A.R. and E.S. All authors have read and agreed to the published version of the manuscript.

Funding: This research was partially funded by the National Center for Research and Development (Poland) in the framework of the H2eBuffer project. Grant Nr POIR.04.01.04-00-0040/20 (2021-2023).

Institutional Review Board Statement: Not applicable.

Informed Consent Statement: Not applicable.

Data Availability Statement: Not applicable.

Acknowledgments: This research was supported by the University of Szczecin, Institute of Management, Cukrowa Street 8, 71-004 Szczecin, Poland.

Conflicts of Interest: The authors declare no conflict of interest.

\section{References}

1. Wach, K.; Głodowska, A.; Maciejewski, M.; Sieja, M. Europeanization Processes of the EU Energy Policy in Visegrad Countries in the Years 2005-2018. Energies 2021, 14, 1802. [CrossRef]

2. Pach-Gurgul, A.; Ulbrych, M. Progress of the V4 Countries towards the EU's Energy and Climate Targets in the Context of Energy Security Improvement. Entrep. Bus. Econ. Rev. 2019, 7, 175-197. [CrossRef]

3. Tvaronavičienè, M.; Prakapienè, D.; Garškaitė-Milvydienė, K.; Prakapas, R.; Nawrot, Ł. Energy Efficiency in the Long-Run in the Selected European Countries. Econ. Sociol. 2018, 11, 245-254. [CrossRef]

4. Shindina, T.; Streimikis, J.; Sukhareva, Y.; Nawrot, Ł. Social and Economic Properties of the Energy Markets. Econ. Sociol. 2018, 11, 334-344. [CrossRef]

5. Hnatyshyn, M. Decomposition analysis of the impact of economic growth on ammonia and nitrogen oxides emissions in the European Union. J. Int. Stud. 2018, 11, 201-209. [CrossRef] [PubMed] 
6. Streimikiene, D. Ranking of Baltic States on progress towards the main energy security goals of European energy union strategy. J. Int. Stud. 2020, 13, 24-37. [CrossRef]

7. Stavytskyy, A.; Kharlamova, G.; Giedraitis, V.; Šumskis, V. Estimating the interrelation between energy security and macroeconomic factors in European countries. J. Int. Stud. 2018, 11, 217-238. [CrossRef]

8. Frankowska, M.; Rzeczycki, A. Hydrogen Supply Chains -New Perspective for Stabilizing Power Grid. Int. J. Latest Res. Eng. Technol. 2021. Available online: https://www.academia.edu/44890883/Hydrogen_Supply_Chains_New_Perspective_for_ Stabilizing_Power_Grid (accessed on 2 November 2021).

9. Hensel, P. A systematic review of the literature in management science and quality. Syst. Rev. Lit. Sci. Manag. Qual. Sci. 2020. [CrossRef]

10. Ren, J.-Z.; Tan, S.; Dong, L. The Assessment of Hydrogen Energy Systems for Fuel Cell Vehicles Using Principal Component Analysis and Cluster Analysis. ISRN Chem. Eng. 2012, 2012, 191308. [CrossRef]

11. Kim, J.; Moon, I. Strategic design of hydrogen infrastructure considering cost and safety using multiobjective optimization. Int. J. Hydrogen Energy 2008, 33, 5887-5896. [CrossRef]

12. Nunes, P.; Oliveira, F.; Hamacher, S.; Almansoori, A. Design of a hydrogen supply chain with uncertainty. Int. J. Hydrogen Energy 2015, 40, 16408-16418. [CrossRef]

13. Li, L.; Manier, H.; Manier, M.A. Hydrogen supply chain network design: An optimization-oriented review. In Renewable and Sustainable Energy Reviews; Elsevier Ltd.: Amsterdam, The Netherlands, 2019; Volume 103, pp. 342-360. [CrossRef]

14. Kim, M.; Kim, J. Optimization model for the design and analysis of an integrated renewable hydrogen supply (IRHS) system: Application to Korea's hydrogen economy. Int. J. Hydrogen Energy 2016, 41, 16613-16626. [CrossRef]

15. De-León Almaraz, S.; Azzaro-Pantel, C.; Montastruc, L.; Domenech, S. Hydrogen supply chain optimization for deployment scenarios in the Midi-Pyrénées region, France. Int. J. Hydrogen Energy 2014, 39, 11831-11845. [CrossRef]

16. Oyekale, J.; Petrollese, M.; Tola, V.; Cau, G. Impacts of renewable energy resources on effectiveness of grid-integrated systems: Succinct review of current challenges and potential solution strategies. Energies 2020, 13, 4856. [CrossRef]

17. Kabir, A.; Gilani, M.S.; Rehmanc, G.; Popp, J.; Hassan, S.A.M.; Oláh, J. Energy-aware caching and collaboration for green communication systems. Acta Montan. Slovaca 2021, 26, 47-59. [CrossRef]

18. Svazas, M.; Navickas, V.; Krajnakova, E.; Nakonieczny, J. Sustainable supply chain of the biomass cluster as a factor for preservation and enhancement of forests. J. Int. Stud. 2019, 12, 309-321. [CrossRef]

19. Ogumerem, G.S.; Kim, C.; Kesisoglou, I.; Diangelakis, N.A.; Pistikopoulos, E.N. A multi-objective optimization for the design and operation of a hydrogen network for transportation fuel. Chem. Eng. Res. Des. 2018, 131, 279-292. [CrossRef]

20. Won, W.; Kwon, H.; Han, J.H.; Kim, J. Design and operation of renewable energy sources based hydrogen supply system: Technology integration and optimization. Renew. Energy 2017, 103, 226-238. [CrossRef]

21. Dominković, D.F.; Gianniou, P.; Münster, M.; Heller, A.; Rode, C. Utilizing thermal building mass for storage in district heating systems: Combined building level simulations and system level optimization. Energy 2018, 153, 949-966. [CrossRef]

22. Acar, C.; Dincer, I. The potential role of hydrogen as a sustainable transportation fuel to combat global warming. Int. J. Hydrogen Energy 2020, 45, 3396-3406. [CrossRef]

23. Hosseini, S.E.; Wahid, M.A. Hydrogen from solar energy, a clean energy carrier from a sustainable source of energy. Int. J. Energy Res. 2020, 44, 4110-4131. [CrossRef]

24. Nikolaidis, P.; Poullikkas, A. Cost metrics of electrical energy storage technologies in potential power system operations. Sustain. Energy Technol. Assess. 2018, 25, 43-59. [CrossRef]

25. Reuß, M.; Grube, T.; Robinius, M.; Preuster, P.; Wasserscheid, P.; Stolten, D. Seasonal storage and alternative carriers: A flexible hydrogen supply chain model. Appl. Energy 2017, 200, 290-302. [CrossRef]

26. Oláh, J.; Krisán, E.; Kiss, A.; Lakner, Z.; Popp, J. PRISMA Statement for Reporting Literature Searches in Systematic Reviews of the Bioethanol Sector. Energies 2020, 13, 2323. [CrossRef]

27. Lahnaoui, A.; Wulf, C.; Heinrichs, H.; Dalmazzone, D. Optimizing hydrogen transportation system for mobility by minimizing the cost of transportation via compressed gas truck in North Rhine-Westphalia. Appl. Energy 2018, 223, 317-328. [CrossRef]

28. Alazemi, J.; Andrews, J. Automotive hydrogen fuelling stations: An international review. Renew. Sustain. Energy Rev. 2015, 48, 483-499. [CrossRef]

29. Fonseca, J.D.; Camargo, M.; Commenge, J.M.; Falk, L.; Gil, I.D. Trends in design of distributed energy systems using hydrogen as energy vector: A systematic literature review. Int. J. Hydrogen Energy 2019, 9486-9504. [CrossRef]

30. Maggio, G.; Nicita, A.; Squadrito, G. How the hydrogen production from RES could change energy and fuel markets: A review of recent literature. Int. J. Hydrogen Energy 2019, 44, 11371-11384. [CrossRef]

31. Mukherjee, U.; Maroufmashat, A.; Narayan, A.; Elkamel, A.; Fowler, M. A stochastic programming approach for the planning and operation of a power to gas energy hub with multiple energy recovery pathways. Energies 2017, 10,868. [CrossRef]

32. Bique, A.O.; Zondervan, E. An outlook towards hydrogen supply chain networks in 2050-Design of novel fuel infrastructures in Germany. Chem. Eng. Res. Des. 2018, 134, 90-103. [CrossRef]

33. Mayyas, A.; Wei, M.; Levis, G. Hydrogen as a long-term, large-scale energy storage solution when coupled with renewable energy sources or grids with dynamic electricity pricing schemes. Int. J. Hydrogen Energy 2020, 45, 16311-16325. [CrossRef]

34. Clúa, J.G.G.; Mantz, R.J.; de Battista, H. Optimal sizing of a grid-assisted wind-hydrogen system. Energy Convers. Manag. 2018, 166, 402-408. [CrossRef] 
35. Yang, G.; Jiang, Y.; You, S. Planning and operation of a hydrogen supply chain network based on the off-grid wind-hydrogen coupling system. Int. J. Hydrogen Energy 2020, 45, 20721-20739. [CrossRef]

36. Gharibi, M.; Askarzadeh, A. Size and power exchange optimization of a grid-connected diesel generator-photovoltaic-fuel cell hybrid energy system considering reliability, cost and renewability. Int. J. Hydrogen Energy 2019, 44, 25428-25441. [CrossRef]

37. Rahimi, S.; Meratizaman, M.; Monadizadeh, S.; Amidpour, M. Techno-economic analysis of wind turbine-PEM (polymer electrolyte membrane) fuel cell hybrid system in standalone area. Energy 2014, 67, 381-396. [CrossRef]

38. Demirhan, C.D.; Tso, W.W.; Powell, J.B.; Heuberger, C.F.; Pistikopoulos, E.N. A Multiscale Energy Systems Engineering Approach for Renewable Power Generation and Storage Optimization. Ind. Eng. Chem. Res. 2020, 59, 7706-7721. [CrossRef]

39. Roberts, T.; Cai, H. Hybrid Renewable Energy System Model Analysis: Pumped Hydrogen Storage Compared to Battery-Bank Storage Systems. In Resilience of the Integrated Building_Proceedings of the Architectural Engineering National Conference; American Enterprise Institute: Washington, DC, USA, 2017; pp. 184-203. [CrossRef]

40. Kong, L.; Yu, J.; Cai, G. Modeling, control and simulation of a photovoltaic /hydrogen/ supercapacitor hybrid power generation system for grid-connected applications. Int. J. Hydrogen Energy 2019, 44, 25129-25144. [CrossRef]

41. Rezaei, M.; Khalilpour, K.R.; Jahangiri, M. Multi-criteria location identification for wind/solar based hydrogen generation: The case of capital cities of a developing country. Int. J. Hydrogen Energy 2020, 45, 33151-33168. [CrossRef]

42. Allahvirdizadeh, Y.; Mohamadian, M.; HaghiFam, M.R.; Hamidi, A. Optimization of a fuzzy based energy management strategy for a PV/WT/FC hybrid renewable system. Int. J. Renew. Energy Res. 2017, 7, 1686-1699. Available online: https: / / ijrer.org/ijrer/index.php/ijrer/article/view/6233 (accessed on 1 February 2021).

43. Lingamuthu, R.R.; Mariappan, R. Power flow control of grid connected hybrid renewable energy system using hybrid controller with pumped storage. Int. J. Hydrogen Energy 2019, 44, 3790-3802. [CrossRef]

44. Lei, G.; Song, H.; Rodriguez, D. Power generation cost minimization of the grid-connected hybrid renewable energy system through optimal sizing using the modified seagull optimization technique. Energy Rep. 2020, 6, 3365-3376. [CrossRef]

45. Bique, A.O.; Maia, L.K.K.; la Mantia, F.; Manca, D.; Zondervan, E. Balancing costs, safety and CO2 emissions in the design of hydrogen supply chains. Comput. Chem. Eng. 2019, 129. [CrossRef]

46. Tlili, O.; Mansilla, C.; Linßen, J.; Reuß, M.; Grube, T.; Robinius, M.; André, J.; Perez, Y.; le Duigou, A.; Stolten, D. Geospatial modelling of the hydrogen infrastructure in France in order to identify the most suited supply chains. Int. J. Hydrog. Energy 2020, 45, 3053-3072. [CrossRef]

47. Lewandowska-Bernat, A.; Desideri, U. Opportunities of power-to-gas technology in different energy systems architectures. Appl. Energy 2018, 228, 57-67. [CrossRef]

48. Belmonte, N.; Girgenti, V.; Florian, P.; Peano, C.; Luetto, C.; Rizzi, P.; Baricco, M. A comparison of energy storage from renewable sources through batteries and fuel cells: A case study in Turin, Italy. Int. J. Hydrogen Energy 2016, 41, 21427-21438. [CrossRef]

49. Li, J.; Lin, J.; Zhang, H.; Song, Y.; Chen, G.; Ding, L.; Liang, D. Optimal Investment of Electrolyzers and Seasonal Storages in Hydrogen Supply Chains Incorporated with Renewable Electric Networks. IEEE Trans. Sustain. Energy 2020, 11, 1773-1784. [CrossRef]

50. Zhang, G.; Shi, Y.; Maleki, A.; Rosen, M.A. Optimal location and size of a grid-independent solar/hydrogen system for rural areas using an efficient heuristic approach. Renew. Energy 2020, 156, 1203-1214. [CrossRef]

51. Kotowicz, J.; Węcel, D.; Jurczyk, M. Analysis of component operation in power-to-gas-to-power installations. Appl. Energy 2018, 216, 45-59. [CrossRef]

52. Farag, H.E.Z.; Al-Obaidi, A.; Khani, H.; El-Taweel, N.; El-Saadany, E.F.; Zeineldin, H.H. Optimal operation management of distributed and centralized electrolysis-based hydrogen generation and storage systems. Electr. Power Syst. Res. $2020,187$. [CrossRef]

53. Bolat, P.; Thiel, C. Hydrogen supply chain architecture for bottom-up energy systems models. Part 1: Developing pathways. Int. J. Hydrogen Energy 2014, 39, 8881-8897. [CrossRef]

54. Dagdougui, H. Models, methods and approaches for the planning and design of the future hydrogen supply chain. Int. J. Hydrogen Energy 2012, 37, 5318-5327. [CrossRef]

55. Samsatli, S.; Samsatli, N.J. A general spatio-temporal model of energy systems with a detailed account of transport and storage. Comput. Chem. Eng. 2015, 80, 155-176. [CrossRef]

56. Demirhan, C.D.; Tso, W.W.; Powell, J.B.; Pistikopoulos, E.N. A multi-scale energy systems engineering approach toward integrated multi-product network optimization. Appl. Energy 2021, 281. [CrossRef]

57. Fazli-Khalaf, M.; Naderi, B.; Mohammadi, M.; Pishvaee, M.S. Design of a sustainable and reliable hydrogen supply chain network under mixed uncertainties: A case study. Int. J. Hydrogen Energy 2020, 45, 34503-34531. [CrossRef]

58. Walker, S.B.; Mukherjee, U.; Fowler, M.; Elkamel, A. Benchmarking and selection of Power-to-Gas utilizing electrolytic hydrogen as an energy storage alternative. Int. J. Hydrogen Energy 2016, 41, 7717-7731. [CrossRef]

59. Mirghaed, M.R.; Saboohi, Y. Optimal design of renewable integrated heat and electricity supply systems with genetic algorithm: Household application in Iran. Int. J. Environ. Sci. Technol. 2020, 17, 2185-2196. [CrossRef]

60. Ali, M.; Ekström, J.; Lehtonen, M. Sizing hydrogen energy storage in consideration of demand response in highly renewable generation power systems. Energies 2018, 11, 1113. [CrossRef] 
61. Blacharski, T.; Kogut, K.; Szurlej, A. The perspectives for the use of hydrogen for electricity storage considering the foreign experience. In E3S Web of Conferences; EDP Sciences: Les Ulis, France, 2017; Volume 14. [CrossRef]

62. Mishchuk, H.; Bilan, S.; Yurchyk, H.; Akimova, L.; Navickas, M. Impact of the shadow economy on social safety: The experience of Ukraine. Econ. Sociol. 2020, 13, 284-298. [CrossRef] 